Volume 6 Issue 4, December 2019

Nationally Accredited Journal,

Decree No. B/4130/E5/E5.2.1/2019

\title{
The Role of the Notary in the Credit Agreement with Mortgage Guarantee (Case Study in the Bank Tabungan Negara (Persero) Tbk)
}

\begin{abstract}
Amalia Chusna ${ }^{1}$ and Jawade Hafiz ${ }^{2}$
Abstract. The purpose of this study was to: 1) Analyze determine and analyze the role of the notary in the completion of the loan agreement with collateral Mortgage PT. Bank Tabungan Negara (Persero) Tbk. 2). Analyzing the causes of a default in settlement of loans with collateral Mortgage PT. Bank Tabungan Negara (Persero) Tbk. 3) Analyze the settlement of disputes in the credit agreement with collateral Mortgage PT. Bank Tabungan Negara (Persero) Tbk.

This research is a field research or empirical research with sociological juridical approach. Sociolegal research done by researching in the field (field research) by means of interviews with respondents who are the primary data and researching library materials is a secondary data and also referred to the research literature. Analysis of data using Qualitative analysis.

The research results are: 1) Task, responsibilities and authority of the Notary is a deed of credit agreement requested by the bank based on information that is clear, to legalize the deed of credit agreement, and is responsible for the correctness, accuracy, completeness of documents, provide counseling to clients / debtors, conceal the identity of the debtor's creditors, enter into a deed of the District Court registry book. 2) Notarial acts as a public official entitled to a deed of credit agreement. And provide legal certainty for the parties to the credit agreement. Besides the role of the Notary as well as the authorities to check against collateral in the form of Encumbrance to ascertain whether goods such guarantee was legal or not, or to avoid if there is a possibility in the collateral Mortgage were made in the warranty is still disputed law or case law. 3) Barriers faced by a Notary is a lack of understanding on banking borrowers, thus providing an explanation to the parties concerned to a mistake in making the agreement can be minimized.

Keywords: Deed; Loan Agreement; Encumbrance.
\end{abstract}

\section{Introduction}

Bank is an entity that collects funds from the public in the form of savings and channel them in the form of loans or other forms in order to improve the lives of many. The business activities of the bank, the bank and the people who take such loans are very concerned to make a credit agreement between them. Based on the interests, between banks and the public who take such loans need for verification. For verification purposes, the bank is very concerned to use the authentic deed evidence, particularly evidence of authentic made by and in the presence of a notary.

On the authority of the notary as a public official maker of the authentic act can be seen in the provisions of Article 15 paragraph (1) of Law No. 30 of 2004 concerning Notary, which stated that: "Notary authorized to make the deed Authentic regarding all the actions of the agreement and the provisions required by law legislation and / or desired by the stakeholders to be stated in the Deed Authentic guaranteed certainty the date of a deed, saving certificates, giving grosse, and a copy of the certificate quotation".

\footnotetext{
${ }^{1}$ Students Master of Notary Program, Unissula, Email: amalia.chusna@btn.co.id

2 Lecturer, Faculty of Law, Sultan Agung Islamic University, Semarang.
} 
Notary in making authentic act can provide certain legal considerations in case of problems as consideration in resolving problems between the parties. Authentic act made by and before a Notary as a public official has a formal proof or material evidence. The position of the notary deed so it gives legal certainty so as to support the establishment of the precautionary principle in the implementation of the provision of credit by the bank. Given the broad scope and elements surrounding this lending activities it is not excessive handling had to be done carefully, supported professionalism and moral integrity that should be attached to the human resources and the loan officer. ${ }^{3}$

In addition to ensuring the smooth installment loans, banks apply certain requirements such as the amount of installment are adjusted by the amount of loans / credits with repayment period, collateral and loan applicant identity. Bank loan applicant must fill out an application, which also includes the deed of credit agreement contains provisions in the agreement which binds both parties. ${ }^{4}$

According to Article 1 paragraph 7 of Law No. 30 of 2004 concerning Notary (UUJN), as amended by Act No. 2 of 2014, the notarial deed is a deed authentic made by or in the presence of a Notary according to the form and manner specified in the Act OF Notary. Through authentic act that clearly defines the rights and obligations, ensure legal certainty, and at the same time is also expected to avoid disputes. Although the dispute can not be avoided, in the dispute resolution process, which is the authentic deeds written evidence gives the strongest and most tangible contribution to the settlement cheaply and quickly. In addition to an authentic deed made by or in the presence of a Notary, not only because it is required by legislation,

One bank credit guarantees commonly used that form of credit guarantees by the imposition Mortgage ground. The role of the notary in the credit agreement with the assurance that a deed Mortgage credit agreements in the form of the Deed of Encumbrances Encumbrance (APHT). Agreement is a legal relationship between two or more parties, based on an agreement to give rise to legal consequences. ${ }^{5}$

In fact the imposition agreement Mortgage did not always go well. Sometimes one of the parties, in particular the debtor in default or break a promise. Default is an act in the form of not implementing the agreement as agreed by the parties. Default can be the contents of the agreement do not carry out entirely, but only partially implement the agreement or implement the contents of the Promised but was too late. At the core of default is a form of action in the form of denial of the agreement.

One of the banks that perform credit agreement on banking activities are performed, namely the Bank Tabungan Negara (Persero) Tbk. As the banks in general the Bank Tabungan Negara (Persero) Tbk also use the services of a notary in performing credit agreements with customers or debtors. Based on the foregoing, this research will be discussed further on Notary Role in the Implementation of the Credit Agreement With Mortgage Guarantee (Case Study in the Bank Tabungan Negara (Persero) Tbk).

This study tried to answer the question about the duties and responsibilities in the implementation of the Credit Agreement Notary, the Notary's role in the Credit Agreement with Guarantee Mortgage and obstacles faced by the Notary and PT. Bank Tabungan Negara Persero Branch Pekalongan in making a credit agreement with a guarantee of Encumbrance.

\footnotetext{
3 Muhammad Djumhana, 2006, Hukum Perbankan Indonesia, Citra Aditya Bakti, Bandung, p.47

${ }^{4}$ Emi Simanjuntak, 2001, Perjanjian Kredit Bank, Universitas Sumatera Utara, p. 3.

${ }^{5}$ Sudikno Mertokusumo, 2001, Mengenal Hukum Suatu Pengantar, Liberty, Yogyakarta, p. 97
} 
Volume 6 Issue 4, December 2019

Nationally Accredited Journal,

Decree No. B/4130/E5/E5.2.1/2019

\section{Research methods}

The approach used in this paper is empirical sociological juridical with the help of primary data or empirical data as the main data. Methods of collecting legal material in this research is with interview and review of literature. The data were analyzed qualitatively normative which analysis is used without the use of numbers and statistics and mathematical formulas presented in the description means. Where the results of the analysis will be presented descriptively.

\section{Results and Discussion}

\subsection{Duties, Responsibilities and Authority of Notary in the Implementation of the Credit Agreement in PT. Bank Tabungan Negara (Persero) Tbk}

In the loan agreement the bank customers should be able to provide certain objects associated as collateral. Law guarantees a certain set of governing or relating to the guarantee in order payable (loan money) contained in various laws that apply today. Credit guarantees under the credit agreement has several functions: ${ }^{6}$

- Credit guarantees as security for repayment of the credit.

- Credit guarantees as a motivator for the debtor.

- Functions related to the implementation of banking.

Submission of credit guarantees by the customer to the bank credit guarantees in the form of securities or in the form of goods (things) so it is a form of guarantee or promise material and debt underwriting so that an assurance or promise material and debt underwriting so that an individual guarantee. Material guarantee entitles the holder of a credit guarantee submitted by the borrower generally be assessed before it is accepted as an object collateral for loans. This includes assessing bank ratings in terms of legal and economic terms. ${ }^{7}$

In the implementation of a credit agreement with Bank, a notary has the duty and authority to:

- Duties and Responsibilities Notary in the credit agreement as a partner PT. Bank Tabungan Negara Branch Office of Pekalongan, after an agreement between the Notary and the bank to work together, then the Notary PPAT has several tasks, among others:

- Duty to make the deed of credit agreement demanded by banks. As the material of the document, the bank must provide data and information that is clearly and specifically explain the type and content of credit documents requested. Notary may not refuse a request in a deed bank credit agreement unless the request of the bank or the facing is contrary to law, public interest and decency.

- He made on credit documents, notary responsible for: Truth, accuracy and completeness of the documents presented; Leaking of bank secrecy, whether performed by a Notary or an employee or employees; The problems of the documents made, if later there was an error or intentional performed by a Notary or an employee or the people who helped her work.

- Notaries charge and responsible for providing guidance, instruction, guidance to banks associated with the loan documents. Legal counseling conducted by a

${ }^{6}$ M.Bahsan 2007, Hukum Jaminan dan Jaminan Kredit Perbankan Indonesia, Raja Grafindo Persada, Jakarta, p. 103

7 Ibid, p.3 
Notary shall be provided to clients in need of legal advice relating to the deed that will be created, because not all of the eloquent and well-informed about the law relating to the agreement to be made Notary through the creation of an authentic deed or deed under the hand.

- Notary in charge of making the final loan documents based on concepts that have been approved by the bank.

- Notaries charge confirmation data to the bank if there are things that are not or less obvious and submit draft documents to the bank.

- Duty to keep secret the name of the Borrower and the amount of credit requested. Objective keep the names debtor and the amount of credit requested so that is not known by the other party because it is considered an internal matter between the parties Notary, Debtor and Creditor.

- Duty to enter into a registry book in order to be registered with the District Court. All certificates that have been created and legalized by Notary must be entered in the register book and registered with the District Court that the deed remains a criminal offense, and if in the future there is a problem related to the deed premises can be resolved according to the rule of law.

- Notary authority in the credit agreement as a partnership of the Bank Tabungan Negara (BTN) Pekalongan:

- The authority to make the deed of loan agreement based on the data and information that is unclear. This is in accordance with the authority of a Notary according to Article 15 (1) of Law No. 30 of 2004 concerning Notary, the Notary authorized to make the authentic act or under the hand in a jurisdiction that has been determined on all deeds, agreements and statutes that may impose by legislation and or desired by the stakeholders to be stated in an authentic deed or deed under hand throughout the making of the deed it not also be assigned or excluded to other officials or any other person specified by the Act.

- Authority to legislate or reject a deed of credit agreement, for reasons which can be accepted by law or for reasons that are detrimental to good credit agreement Creditor and Debtor. This is in accordance with the authority of a Notary according to Article 15 paragraph (2) a of Law No. 30 of 2004 concerning Notary stating the authority of a Notary is to do the legalization certificates, among others certify the signatures and set a firm date that the letter under the handmade by parties concerned with registering on a special book that has been provided by the Notary.

- The authority to certify if the terms of the completeness of the file have not been met by the Debtor or creditor. These files are used Notary for administration in connection with the manufacture of the requested certificate to the Notary.

- Authority to request payment for its services in the form of money from the bank on the manufacture, maintenance and completion of documents that have been done, as determined on the basis of agreement between the customer and Partner known by the bank, taking into account the difficulty level of the work, its prevalence and the applicable regulations.

\subsection{The Role of the Notary in the Credit Agreement with Mortgage Guarantee on PT. Bank Tabungan Negara (Persero) Tbk}

The existence of a notary can not be separated from the needs of society on the importance of strong evidence in any legal events. Therefore, the notary and his duty to the community should be fine. It can only be accomplished if the notary act and be 
Volume 6 Issue 4, December 2019

Nationally Accredited Journal,

Decree No. B/4130/E5/E5.2.1/2019

guided in accordance with what is stated in the Act of Notary and Notary Code. Both of these provisions are equipped with strict sanctions for the offenders. ${ }^{8}$

A cooperation agreement between the bank and the notary had violated Law of Notary and Notary Code provisions. Based on the consideration that the notary has frequently been asked the bank makes a loan agreement under bank intervention. Treaty clause is mostly determined by the bank, but it is basically a notary public office should certainly serve the interests of society facing him without any previous binding. In terms of lending constituted with a credit agreement, the credit agreement may call for special attention by both the bank as a creditor or by the customer as a debtor, because the credit agreement has a very important function in the provision, management and credit management itself. ${ }^{9}$

The results of the study that PT. Bank Tabungan Negara in carrying out banking activities also has a peer or partner to facilitate banking activities, for example, PT. Bank Tabungan Negara Branch Office of Pekalongan have a Notary PPAT colleagues in making a credit agreement, because when PT. Bank Tabungan Negara would like to make a credit agreement by using Collateral Mortgage PT. Bank Tabungan Negara should colaborate by a notary that serves to determine that the collateral that will be used later is a guarantee of legitimate goods and not problematic before the law and authorize or legalize the agreement to be made.

Notary in becoming a partner of PT. Bank Tabungan Negara has a role as a public official is entitled to a deed of credit agreement which has the duty and the authority which it is responsible. A task that has, among a deed of credit agreement demanded by banks, providing guidance to banks associated with the loan documents, make credit documents are final, confirmation data to the bank if there are things that are not or less clear, keeping secret the name of the Borrower and the number of credit requested, and enter into a registry book in order to registered at the Court.

The role of the notary in the system of lending conducted by the bank is to provide legal certainty for the parties to the credit agreement, besides the role of the Notary as well as the authorities to check against collateral in the form of Encumbrance to ascertain whether the goods the guarantee is valid in eyes of the law or not, or to avoid if there is a possibility in which the collateral Mortgage guarantees made in the extant legal dispute or case law. Deed of agreement legalized or warmerking and checked by a notary is something that is done to reduce the negative factor as that achievement was given in the form of money, goods,

Notary also has an additional role as a credit agreement between PT. Bank Tabungan Negara and its customers is completed, the Notary must go to office BPN to make the process Roya against the collateral used in the deal because if this is not done by a Notary after the deal is completed, it can give rise to a legal case in which the collateral is still tied to collateral agreements before causing collateral can not be used again as collateral Mortgage in the credit agreement in the next agreement, because in the Land office records Mortgage collateral is still tied to an agreement with the previous agreement,

\footnotetext{
${ }^{8}$ Wirjono prodjodikoro, 2000, Perbuatan Melanggar Hukum, Mandar Maju, Bandung, p. 6. ${ }^{9}$ Means Widia and Adrian Sutedi 2006, Implikasi Hak Tanggungan Terhadap Pemberian Kredit Oleh Bank dan Penyelesaian Kredit, Cipta Jaya, Jakarta, p. 43.
} 


\subsection{Barriers faced by Notary and PT. Bank Tabungan Negara Persero Branch Pekalongan in making a Credit Agreement with a Guarantee of Encumbrance}

Whereas in the implementation lending by banks do not always run smoothly as expected so the banks must also be cautious and wise in giving a loan or a credit to the people and always pay attention to the principles that have been set up, the degree of risk (risk), achievement / object credit and collateral (the provisions of Law No. 10 of 1998 on Banking Article 1, point 11). ${ }^{10}$ Therefore it is very necessary role of the Notary to provide insight, information and insight to both parties before implementing the credit agreement in order to minimize future disputes between the two sides. Notaries must be able to cooperate with the bank to issue a notary deed required in a credit agreement which would be made by the bank or the so-called creditors. ${ }^{11}$

Barriers faced by Notary and PT. Bank Tabungan Negara Persero Branch Pekalongan in making a credit agreement with a guarantee Encumbrance namely:

- Obstacles that come from banks, namely:

- Negligence bank clerk. Lack of or incomplete files of the Borrower for negligence bank officer, because ID cards expired. Perfect credit agreement was that meets the requirements that specify the identity of the loan, the loan amount, the interest rate, the use of the loan, the name or the shape of goods, the place and the location of items of collateral. The solution used Notary in the face of these obstacles that appealed to the bank officer to be in receipt of the request for credit from a client needs to get more attention to focus the examination of formal requirements secar meticulous about the identity of the parties including ensuring sound signature and check files more of the Borrower relating to the request for credit.

- Section head of the credit department is unable. How important the credit agreement in the legal aspect, particularly as a means of proof in general. The difficulty is when the head of the sub-section that credit hindered the implementation of the agreement kerdit or acknowledgment of debt itself will retreat, and automatic disbursement of the loan will be delayed, solutions that do Notary in the face of these obstacles are immediately sent head of the bank from the branch office to appoint the head section part credit temporary replacement so that the realization of the disbursement of loan funds is not too late

- Barriers are derived from the Borrower

- Lack of understanding of the banking and credit agreements, so the solution is to adopt an explanation and understanding prior to the binding process of the agreement.

- Their cases have not been behind the name of the name of the certificate is used as Encumbrance and accuracy of the promise by the debtor Constraints on the ground of perceived Notaries in implementing the loan agreement with collateral Mortgage covers on the state certificate of property that will serve as Encumbrance by the customer is not behind the name so Notaries must perform a double check and make the certificate is behind the name on the current owner or the notary must bring the old certificate owner for questioning signature.

\footnotetext{
${ }^{10}$ Hermansyah, 2005, Hukum Perbankan Nasional Indonesia, Prenada Media, Jakarta, p. 20.

11 J. Satrio, Security Law, 2002, Hak Jaminan Kebendaan, Hak Tanggungan, Citra Aditya Bakti, Bandung, p. 21.
} 
Volume 6 Issue 4, December 2019

Nationally Accredited Journal,

Decree No. B/4130/E5/E5.2.1/2019

Notary solution before do manufacture prior credit agreement the parties concerned in the making of the agreement together about the certainty of checking the certificate in order to avoid be discovered certificate has not been behind the name when they will realize the agreement,

- Another constraint is also located on the promise that created the Notary and PT. Bank Tabungan Negara Persero (PT) Branch should be delayed liste it for appointments at agreed upon delayed or not timely caused by the customer as a debtor, which sometimes can not be present so that the provision of a signature in the agreement can not be done simultaneously due one party client can not be present and must be followed to give his signature thus slowing down the process of making the agreement.

\section{Closing}

\subsection{Conclusion}

Based on the description above, the conclusions of this research are:

- Duties, responsibilities and authority of the Notary in the implementation of the credit agreement at PT. Bank Tabungan Negara (Persero) Tbk, namely as a partner PT. Bank Tabungan Negara (Persero) Tbk to a deed of credit agreement requested by the bank based on information that is clear, to legalize the deed of credit agreement, and is responsible for the correctness, accuracy, completeness of documents, provide counseling to the client / debtor, conceal the identity of the debtor's creditors, enter deed Court into the registry book.

- The role of the Notary in the Credit Agreement with Mortgage Guarantee on PT. Bank Tabungan Negara (Persero) Tbk, which acts as a public official has the right to make the deed of credit agreement. The role of the notary in the system of lending conducted by the bank is to provide legal certainty for the parties to the credit agreement, besides the role of the Notary as well as the authorities to check against collateral in the form of Encumbrance to ascertain whether the goods the guarantee is valid in eyes of the law or not, or to avoid if there is a possibility in which the collateral Mortgage guarantees made in the extant legal dispute or case law.

- Barriers faced by Notary and PT. Bank Tabungan Negara Persero Branch Pekalongan in making a credit agreement with a guarantee that the negligence Mortgage bank clerk in examine the complete document, section head of the credit department are unable to attend, the debtor's lack of understanding about the banking system and guarantee mortgages have not been behind the name. Solutions done is to give an explanation to the relevant parties so that errors in making the agreement can be minimized.

\subsection{Suggestion}

- Should the public better understand and find out before making a credit agreement in the bank, this is done in order not be used by those less responsible.

- The bank should be more careful in checking the documents of the debtor, in order to minimize errors.

- The parties in order to arrive on time as promised that made notary, so that a deed agreement to be realized.

\section{References}


[1] Emi Simanjuntak, 2001, Perjanjian Kredit Bank, Universitas Sumatera Utara

[2] Hermansyah, 2005, Hukum Perbankan Nasional Indonesia, Prenada Media, Jakarta

[3] J. Satrio, Hukum Jaminan, 2002, Hak Jaminan Kebendaan, Hak Tanggungan, Citra Aditya Bakti, Bandung

[4] Kartini Muljadi dan Gunawan Widjaja, 2005, Hak Tanggungan, Kencana Jakarta

[5] Law No. 10 of 1998 on the Amendment of Law No. 7 of 1992 concerning Banking

[6] Law No. 2 of 2014 concerning Notary

[7] M.Bahsan, 2007, Hukum Jaminan dan Jaminan Kredit Perbankan Indonesia, Raja Grafindo Persada, Jakarta

[8] Muhammad Djumhana, 2006, Hukum Perbankan Indonesia, Citra Aditya Bakti, Bandung

[9] Sarana Widia dan Adrian Sutedi, 2006, Implikasi Hak Tanggungan Terhadap Pemberian Kredit Oleh Bank dan Penyelesaian Kredit, Cipta Jaya, Jakarta

[10] Sudikno Mertokusumo, 2001, Mengenal Hukum Suatu Pengantar, Liberty, Yogyakarta

[11] Wirjono Prodjodikoro, 2000, Perbuatan Melanggar Hukum, Mandar Maju, Bandung 